\title{
$\triangle$ ACRIFO $\Rightarrow$ \\ KETERKAITAN DAN DAMPAK KARAKTERISTIK SOSIAL PETANI TERHADAP PRODUKSI PADI DI KABUPATEN ACEH UTARA
}

\section{Zuriani $^{1}$}

\section{Email: zuriani2006@yahoo.co.id}

\begin{abstract}
This research is motivated by the farmers who are generally less educated and have a mindset that is difficult to be invited to change. The aim of the study was to analyze the impact of the social characteristics of farmers on rice production in North Aceh district. The data used is a cross section taken in February 2012 based on the growing season in 2011. The method used is multiple linear regression analysis. The results showed that social characteristics turns rice farmers consisting of age, education, number of dependents and simultaneously farming experience no significant effect on rice production in the district of Sawang. While partially, age and farming experience significant effect on the level of confidence of $10 \%$ of the rice production.
\end{abstract}

Keywords: social characteristics, rice farmers and rice production.

\section{PENDAHULUAN}

Kabupaten

Aceh merupakan sentral penghasil padi di
Provinsi Aceh dengan luas tanam mencapai 56.627 hektar dan produksi total sebanyak 285.019,80 ton (BPS Provinsi Aceh, 2010). Diantara kecamatan-kecamatan penghasil padi di Kabupaten Aceh Utara, Kecamatan Sawang merupakan Kecamatan dengan nilai produktivitas tertinggi yaitu sebesar $94.90 \mathrm{kwintal} /$ hektar (BPS Aceh Utara, 2010). Jumlah petani padi sawah di Kecamatan Sawang mencapai 3.976 rumah tangga dengan karakteristik sosial yang beraneka ragam. Karakteristik sosial yang dimaksud terdiri dari umur, tingkat pendidikan, jumlah tanggungan, dan pengalaman berusahatani.
Karakteristik sosial yang dimiliki oleh masing-masing petani akan berpengaruh kepada keputusan yang diambil dalam berusahatani. Hal ini secara tidak langsung akan berpengaruh terhadap produksi yang mereka dapatkan. Yang menjadi permasalahan dalam penelitian ini adalah bagaimana dampak karakteristik sosial petani terhadap produksi padi sawah di Kabupaten Aceh Utara. Oleh karena itu, perlu dilakukan suatu penelitian untuk mengetahui dampak karakteristik sosial petani terhadap produksi padi sawah di Kabupaten Aceh Utara. Penelitian ini bertujuan untuk menganalisis dampak karakteristik sosial petani terhadap produksi padi sawah di Kabupaten Aceh Utara. Kegunaan yang diharapkan dari

\footnotetext{
${ }^{1}$ Staff Pengajar Fakultas Pertanian Universitas Malikussaleh
} 
penelitian adalah dapat menjadi sebagai referensi bagi petani dan pemerintah dalam mewujudkan ketahanan pangan di Provinsi Aceh.

Penelitian terdahulu yang menjadi pendukung penelitian ini adalah yang mengenai analisis pengaruh sumber daya manusia (sdm) petani terhadap pendapatan petani padi sawah. Metode yang digunakan untuk menganalisis data penelitian adalah Ordinary Least Square dengan analisis regresi linier berganda. Hasil penelitian menunjukkan bahwa dari hasil estimasi secara serempak (bersama-sama) sumber daya manusia memiliki pengaruh nyata terhadap pendapatan petani padi sawah. Secara parsial pencurahan tenaga kerja dan frekuensi mengikuti penyuluhan/pelatihan memiliki pengaruh nyata terhadap pendapatan petani, sedangkan pendidikan dan lamanya berusahatani tidak terdapat pengaruh nyata terhadap pendapatan petani padi sawah. Dan secara serempak (bersama-sama) karakteristik petani (Umur, Luas Lahan, Jumlah Tanggungan, dan Modal) memiliki pengaruh nyata terhadap pendapatan petani padi sawah. Secara persial yang memiliki pengaruh nyata terhadap pendapatan petani adalah luas lahan (Alfan Bachtar Harahap at. Al., 2012).

\section{METODE PENELITIAN}

\section{Metode Pemilihan Lokasi}

Penelitian ini berlokasi di Kecamatan Sawang yang ditentukan secara sengaja (purposive) dengan pertimbangan bahwa Kecamatan Sawang merupakan sentra produksi padi di Kabupaten Aceh Utara.

\section{Metode Penarikan Sampel}

Metode penarikan sampel yang digunakan adalah Simple Random Sampling (pengambilan sampel secara acak sederhana) dimana semua populasi memiliki peluang yang sama untuk menjadi sampel. Ukuran sampel adalah 30 orang yang diambil dari tiga desa terpilih berdasarkan luas lahan sawah dengan distribusi sampel seperti pada Tabel

Tabel 1. Distribusi Petani Sampel Berdasarkan Desa

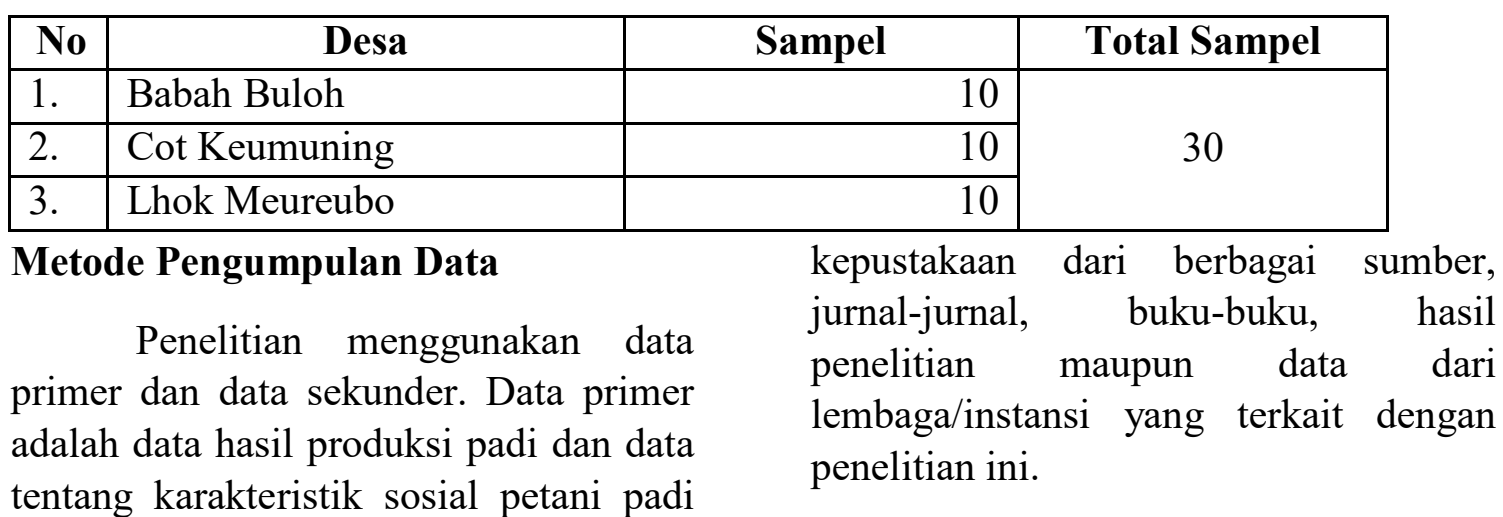
sawah yang terpilih sebagai sampel. Data sekunder meliputi data penunjang yang diambil secara runtun waktu (time series), yang didapatkan melalui studi

\section{Metode Analisis Data}

Analisis dampak karakteristik sosial petani terhadap produksi padi 
sawah menggunakan analisis regresi linier berganda. Yang bertujuan untuk menganalisis pengaruh dari variabel independen (pendidikan, umur, pengalaman berusahatani, dan jumlah tanggungan) terhadap variabel dependen (produksi padi). Adapun rumus Regresi Linier Berganda yang digunakan ada $Y \quad 1 U$ 2Pd $3 J t 4 P e$ (Gujarati, 2003)

\section{Dimana:}

$$
\begin{array}{ll}
\wedge & : \text { Produksi Padi (Kg) } \\
U & : \text { Umur (Tahun) } \\
P d & : \text { Pendidikan (Tahun) }
\end{array}
$$

JT : Jumlah Tanggungan (Jiwa)

$P$ :Pengalaman berusahatani (Tahun)

\section{HASIL DAN PEMBAHASAN}

\section{Karakteristik Sosial Petani Terhadap Produksi Padi sawah}

Berdasarkan hasil penelitian diketahui bahwa karakteristik sosial petani memiliki variasi, baik dalam bidang pendidikan, umur, pengalaman, maupun jumlah tanggungan. Berikut deskripsi karakteristik sosial petani padi sawah di lokasi penelitian.

Tabel 2. Deskripsi karakteristik sosial petani padi sawah di Kecamatan Sawang

\begin{tabular}{|l|l|r|r|r|}
\hline \multirow{2}{*}{ Uraian } & \multirow{2}{*}{ Satuan } & \multicolumn{2}{|c|}{ Range } & \multirow{2}{*}{ Rata-rata } \\
\cline { 3 - 4 } & & Terendah & \multicolumn{1}{c|}{ Tertinggi } & \\
\hline Umur & Tahun & 25 & 71 & 48,56 \\
\hline Pendidikan & Tahun & 6 & 12 & 8,3 \\
\hline Jumlah Tanggungan & Jiwa & 1 & 12 & 4,3 \\
\hline Pengalaman & Tahun & 5 & 50 & 27,56 \\
\hline
\end{tabular}

Umur seseorang berpengaruh terhadap keputusan dan kemampuan aktifitas fisiknya. Umur berkaitan jelas dengan kinerja dan produktifitasnya. Semakin bertambah usia seseorang maka kemampuan untuk melakukan suatu pekerjaan cenderung menurun. Rata-rata umur sampel adalah 48,56 tahun, menunjukkan bahwa sampel tergolong usia produktif. Simanjuntak (1985) mengelompokkan usia produktif adalah mereka yang berada pada kelompok umur 15-55 tahun. Pada kelompok usia produktif, kemampuan untuk melakukan usahatani diperkirakan masih relatif tinggi.

Sumber daya manusia yang diukur dari tingkat pendidikan yang merupakan faktor penting dalam mengakomodasi teknologi maupun ketrampilan dalam usahatani padi. Kategori pendidikan meliputi pendidikan formal yang secara kuantitatif diukur dengan jumlah tahun mengikuti pendidikan yang selanjutnya disetarakan dengan tahapan tingkat pendidikan umum. Pembahasan mengenai pendidikan dimaksudkan untuk mengetahui tingkat kemampuan sampel dalam mengelola usahataninya. Hal ini terkait dengan berbagai informasi diantaranya pengetahuan sampel terhadap pemupukan dan pembudidayaan yang sesuai untuk tanaman padi sawah. Data yang tersaji memperlihatkan bahwa rata-rata pendidikan sampel adalah 8.3 tahun atau setara dengan pendidikan Sekolah 
Menengah Pertama (SMP). Maka pengelolaan usahatani padi lebih hanyak hanya menitikberatkan pada kemampuan teknis yang diperoleh secara turun temurun, disamping mendapatkan pelatihan tehnis dari instansi terkait. Sehingga dengan berbekal pengalaman tersebut dapat berpengaruh terhadap hasil produksi padi.

Jumlah anak yang menjadi tanggungan sangat mempengaruhi pengeluaran sampel. Semakin banyak jumlah tanggungan keluarga maka semakin tinggi pengeluaran untuk barang konsumtif. Bila tidak didukung dengan pendapatan rumah tangga yang memadai maka sampel akan mengurangi jumlah pengeluaran untuk usahatani, dan hal ini juga akan mempengaruhi pola usahatani padi sawah yang dikelola oleh sampel tersebut. Jumlah tanggungan sampel rata-rata sebanyak 4 orang. Selain itu, jumlah tanggungan juga menunjukkan ketersediaan tenaga kerja dalam keluarga yang siap digunakan dalam usahatani padi.

$$
\text { Petani sampel mempunyai }
$$
pengalaman yang bervariasi dalam usahatani padi, sebagian besar petani mempunyai pengalaman dalam usahatani padi 5-50 tahun. Hal ini menunjukkan bahwa petani sampel adalah petani tradisional yang secara naluri mampu mengelola faktor-faktor produksi

\section{Keterkaitan karakteristik Sosial Petani dengan Produksi Padi sawah}

Untuk mengetahui keterkaitan karakteristik sosial petani dengan produksi padi sawah dilakukan analisis korelasi dengan metode pearson. Berikut hasil analisis korelasi antara umur, pendidikan, jumlah tanggungan, dan pengalaman dengan produksi padi sawah di daerah penelitian.

Tabel 3. Keterkaitan karakteristik sosial petani dengan produksi padi sawah

\begin{tabular}{llrrrrr}
\hline & \multicolumn{3}{c}{$\begin{array}{c}\text { produksi } \\
\text { padi }\end{array}$} & umur pendidikan $\begin{array}{c}\text { jumlah } \\
\text { tanggungan pengalaman }\end{array}$ \\
Pearson & produksi & & & & & \\
Correlation & padi & 1.000 & .000 & -.163 & .183 & .265 \\
& Umur & .000 & 1.000 & -.370 & .556 & .735 \\
& Pendidikan & -.163 & -.370 & 1.000 & -.369 & -.414 \\
& jumlah & .183 & .556 & -.369 & 1.000 & .569 \\
& tanggungan & .265 & .735 & -.414 & .569 & 1.000 \\
\hline
\end{tabular}

$\begin{array}{lll}\text { Dari tabel di atas terlihat bahwa } & \text { yang banyak pula. Hal ini dikarenakan } \\ \text { hanya jumlah tanggungan dan } & \text { sebagian besar jumlah tanggungan } \\ \text { pengalaman yang memiliki korelasi } & \text { petani merupakan tenaga kerja dalam } \\ \text { positif dengan produksi padi sawah di } & \text { keluarga yang selalu siap diandalkan } \\ \text { Kecamatan Sawang. Petani yang } & \begin{array}{l}\text { untuk kesuksesan usahatani. Selain itu, } \\ \text { memiliki jumlah tanggungan yang }\end{array} \\ \text { banyak akan mendapatkan produksi } & \text { berkaitan erat dengan biaya hidup yang }\end{array}$


harus dikeluarkan, semakin banyak jumlah tanggungan maka semakin besar pula tanggungan nafkah yang harus dipenuhinya. Oleh karena itu, petani semakin termotivasi untuk mendapatkan hasil yang lebih banyak. Pengalaman merupakan satu-satunya variabel yang berhubungan signifikan dengan produksi. Koefisien korelasi menunjukkan hubungan yang lemah, namun pertambahan pengalaman akan memberikan tambahan produksi yang signifikan. Hal ini disebabkan karena petani mendapatkan pengetahuan dari usahatani yang mereka kelola. Semakin lama mereka bertani maka pengalaman dan pengetahuan yang mereka miliki semakin tinggi sehingga kemampuan mereka untuk mendapatkan hasil yang maksimal juga semakin banyak.

Umur berhubungan negatif

sangat lemah dengan produksi padi karena koefisien korelasinya negatif mendekati nol. Hal ini menunjukkan bahwa umur seseorang tidak mampu menjamin kesuksesan usahatani yang mereka kelola. Umur yang tua tetapi tidak dibarengi dengan pengalaman dan pengetahuan yang memadai maka tidak akan bisa mengelola usahatani dengan baik. Pendidikan berhubungan negatif dengan produksi, yang berarti bahwa petani yang berpendidikan tinggi memiliki jumlah produksi padi yang rendah.

\section{Dampak Karakteristik Sosial Petani Terhadap Produksi Padi sawah}

Untuk mengetahui dampak dari masing-masing karakteristik sosial petani tersebut terhadap produksi padi dilakukan analisis regresi berganda dengan persamaan:

$$
Y \quad 1 U 2 P d 3 J t 4 P e \text {, }
$$

(Gujarati, 2003)

Dimana :

$$
\begin{array}{ll}
\wedge & : \text { Produksi Padi (Kg) } \\
U & \text { : Umur (Tahun) } \\
P d & \text { : Pendidikan (Tahun) } \\
J T & \text { : Jumlah Tanggungan (Jiwa) } \\
P & \text { :Pengalaman berusahatani } \\
\text { (Tahun) }
\end{array}
$$

Berdasarkan hasil analisis regresi menggunakan software SPSS versi 16.0 diperoleh hasil sebagai berikut.

Tabel 4. Hasil Analisis Dampak Karakteristik Sosial Petani terhadap Produksi Padi Sawah di Kecamatan Sawang

\begin{tabular}{lrr}
\multicolumn{1}{c}{ Variabel } & Koefisien & Nilai signifikan \\
\hline (Constant) & 2557.480 & .079 \\
Umur & -46.217 & .099 \\
Pendidikan & -36.371 & .693 \\
jumlah tanggungan & 64.804 & .585 \\
Pengalaman & 46.742 & .086 \\
\hline
\end{tabular}

Sumber: Hasil pengolahan data primer (Lampiran 5)

Berdasarkan Tabel 4 di atas dapat yang signifikan (pada taraf $10 \%$ atau diketahui bahwa hanya umur dan $0,10)$ terhadap produksi padi di pengalaman yang memiliki pengaruh Kecamatan Sawang. Koefisien regresi 
umur diperoleh sebesar $-46,217$ menunjukkan bahwa peningkatan umur petani sebanyak 1 tahun akan menurunkan produksi padi sebanyak 46,217 kg. Hal ini disebabkan karena ketika umur petani semakin tua maka produktivitasnya semakin berkurang. Petani di lokasi penelitian semuanya bertindak sebagai pekerja utama, hampir semua kegiatan membutuhkan keterlibatan mereka. Kondisi inilah yang menyebabkan produksi juga akan menurun seiring berkurangnya produktivitas petani. Koefisien regresi pengalaman sebesar 46, 472 yang berarti bahwa setiap peningkatan pengalaman satu tahun maka akan mampu meningkatkan produksi sebesar 46, 472 $\mathrm{kg}$. Kondisi ini menunjukkan bahwa petani yang lebih berpengalaman akan memiliki kemampuan untuk mengelola usahatani yang lebih baik sehingga produksi yang didapatkan bisa lebih banyak. Pendidikan dan jumlah tanggungan tidak berpengaruh nyata terhadap produksi padi di Kecamatan Sawang.

\section{KESIMPULAN DAN SARAN}

\section{Kesimpulan}

1. Variabel yang berhubungan positif dengan produksi padi sawah di Kecamatan Sawang adalah jumlah tanggungan dan pengalaman.

2. Variabel yang berpengaruh signifikan pada taraf $10 \%$ terhadap produksi padi Kecamatan Sawang adalah umur dan pengalaman. Sedangkan pendidikan dan jumlah tanggungan tidak berpengaruh nyata terhadap produksi padi di Kecamatan Sawang.

\section{Saran}

1. Pemerintah untuk memberikan penyuluhan secara lebih intensif seperti demontrasi plot tetang tata cara pengelolaan usahatani padi sawah yang tepat.

2. Petani untuk lebih pro aktif dalam mencari informasi terkait dengan pengelolaan usahatani padi sawah serta lebih serius dalam mengaplikasikan pengalaman yang mereka miliki dalam melakukan usahatani supaya bisa mendapatkan produksi yang lebih banyak.

\section{DAFTAR PUSTAKA}

Alfan Bachtar Harahap at.al., 2012. pengaruh sumber daya manusia (sdm) petani terhadap pendapatan petani padi sawah (Studi Kasus : Desa Pematang Setrak, Kec Teluk Mengkudu, Kab Serdang Bedagai). http:// download.portalgaruda.org. 28 Maret 2014.

BPS. 2010. Provinsi Aceh Dalam Angka Tahun 2010. Biro Pusat Statistik, Provinsi Aceh.

BPS. 2010. Aceh Utara Dalam Angka Tahun 2010. Biro Pusat Statistik, Kabupaten Aceh Utara.

Dinas Pertanian dan Tanaman Pangan Aceh Utara, 2011. Pemupukan Tanaman Padi Sawah. Kabupaten aceh Utara.

Gujarati, Damodaar N. 2003. Basic Econometricse, Fourtd Edition, Mc Graw Hill.

Payaman J. Simanjuntak, 1995, Pengantar Ekonomi Sumber Daya Manusia, LPFE UI, Jakarta 
Lampiran 1. Tabel Luas Tanam, Luas Panen, Produksi, dan produktivitas Padi Sawah per Kecamatan di Kabupaten Aceh Utara

\begin{tabular}{|c|c|c|c|c|}
\hline Kecamatan & $\begin{array}{l}\text { Luas tanam } \\
\text { (ha) }\end{array}$ & $\begin{array}{c}\text { Luas panen } \\
\text { (ha) }\end{array}$ & $\begin{array}{c}\text { Produktivitas } \\
\text { (kw/ha) }\end{array}$ & $\begin{array}{l}\text { Produksi } \\
\text { (ton) }\end{array}$ \\
\hline 1. Sawang & 3.621 & 3.221 & 94,90 & $30.567,29$ \\
\hline 2. Nisam & 2.943 & 2.941 & 76,91 & $22.619,23$ \\
\hline 3. Muara batu & 4.565 & 3.043 & 65,32 & $19.876,88$ \\
\hline 4. Kuta makmur & 2.771 & 2.751 & 60,90 & $16.753,59$ \\
\hline \multicolumn{5}{|l|}{ 5. Simpang } \\
\hline kramat & דיד & ד.TU & U & $8.393,11$ \\
\hline 6. Lhoksukon & 2.260 & 2.055 & 58,65 & $12.052,58$ \\
\hline 7. Dewantara & 745 & 745 & 55,37 & $4.125,07$ \\
\hline \multirow{2}{*}{$\begin{array}{l}\text { 8. Meurah mulia } \\
\text { 9. Tanah jambo } \\
\text { sva }\end{array}$} & 2.673 & 2.673 & 52,86 & $14.129,48$ \\
\hline & 4.700 & 4.700 & 50,87 & 720080 \\
\hline 10.Langkahan & 2.154 & 2.154 & 50,43 & $10.862,62$ \\
\hline 11.Baktiya & 7.511 & 7.575 & 48,62 & $36.829,65$ \\
\hline 12.Nibong & 975 & 975 & 47,84 & $4.664,4$ \\
\hline 13.Banda baro & 1.038 & 1.068 & 47,33 & $50.54,84$ \\
\hline 14.Cot girek & 613 & 613 & 45,78 & $2.897,87$ \\
\hline 15.Seunuddon & 3.423 & 3.423 & 45,07 & $16.815,62$ \\
\hline $\begin{array}{c}\text { 16. Geureudong } \\
\text { nnco }\end{array}$ & 433 & 433 & 44,62 & 1027 n5 \\
\hline 17.Tanah luas & 1.473 & 1.359 & 43,95 & $5.972,81$ \\
\hline 18.Syamtalira bayu & 1.315 & 1.315 & 43,95 & $5.779,43$ \\
\hline 19.Samudera & 1.583 & 1.583 & 43,69 & $6.916,13$ \\
\hline 20.Baktiya barat & 2.001 & 2.006 & 42,91 & $8.607,75$ \\
\hline 21Paya bakong & 1.818 & 1.413 & 39,02 & $5.513,53$ \\
\hline 22.Syamtalira aron & 1.260 & 1.100 & 36,25 & $3.987,5$ \\
\hline 23.Pirak timu & 506 & 506 & 35,81 & $1.811,99$ \\
\hline 24.Lapang & 912 & 621 & 35,77 & $2.221,32$ \\
\hline 25.Matang kuli & 2.660 & 2.660 & 34,86 & $9.272,76$ \\
\hline 26.Tanah pasir & 1.270 & 1.059 & 32,61 & $3.453,4$ \\
\hline \multirow[t]{2}{*}{ 27.Nisam antara } & - & - & - & - \\
\hline & 56.627 & 53.724 & 53,05 & $285.019,80$ \\
\hline
\end{tabular}

Sumber :Biro Pusat Statistik Kabupaten Aceh Utara, 2010 
Lampiran 2. Luas Lahan Sawah dan Jumlah Rumah Tangga Petani Tanaman Pangan per Desa di Kecamatan Sawang

\begin{tabular}{|c|c|c|c|}
\hline No & Desa & $\begin{array}{c}\text { Luas Lahan sawah } \\
\text { (ha) }\end{array}$ & $\begin{array}{c}\text { Rumah Tangga Petani } \\
\text { (Unit) }\end{array}$ \\
\hline 1. & Paya Gaboh & 16 & , \\
\hline 2. & Ulee Geudong & 64 & 97 \\
\hline 3. & Cot Keumuning & 51 & 33 \\
\hline 4. & Tanjong Keumala & 41 & 47 \\
\hline 5. & Abeuk Reuling & 26 & 29 \\
\hline 6. & Lhok Krek & 33 & 63 \\
\hline 7. & Cot Lambideng & 72 & 93 \\
\hline 8. & Lagang & 61 & 81 \\
\hline 9. & Lhok Meureubo & 11 & 35 \\
\hline 10. & Kuta Meuligoe & 51 & 86 \\
\hline 11. & Glee Dagang & 51 & 140 \\
\hline 12. & Gampong Teungoh & 111 & 155 \\
\hline 13. & Pante Jaloh & 41 & 50 \\
\hline 14. & Lhok Kuyun & 46 & 39 \\
\hline 15. & Blang Reuling & 75 & 140 \\
\hline 16. & Babah Buloh & 301 & 179 \\
\hline 17. & Meunasah Pulo & 101 & 91 \\
\hline 18. & Punteut & 76 & 107 \\
\hline 19. & Teupin Reusep & 40 & 313 \\
\hline 20. & Paya Rabo Timur & 15 & 44 \\
\hline & Paya Rabo Lhok & 45 & 112 \\
\hline 22. & Lhok Gajah & 31 & 47 \\
\hline 23. & Krueng Baro & 50 & 62 \\
\hline 24. & Lhok Bayu & 15 & 41 \\
\hline 25. & Lancok & 33 & 85 \\
\hline 26. & Blang Manyak & 33 & 46 \\
\hline 27. & Rambong Payong & 16 & 40 \\
\hline & Jurong & 35 & 106 \\
\hline & Babah Krueng & 50 & 134 \\
\hline & Lhok Jok & 34 & 46 \\
\hline & Sawang & 93 & 288 \\
\hline 32. & Blang Teurakan & 40 & 93 \\
\hline & Lhok Cut & 60 & 55 \\
\hline 34. & Kubu & 42 & 70 \\
\hline & Blang Cut & 50 & 68 \\
\hline 36. & Gunci & 87 & 324 \\
\hline 37. & Riseh Baroh & 50 & 97 \\
\hline 38. & Riseh Teungoh & 32 & 52 \\
\hline & Total & 2111 & \\
\hline & Rata-rata & 54,13 & \\
\hline
\end{tabular}

Sumber :Biro Pusat Statistik Kabupaten Aceh Utara, 2010 
Lampiran 3. Data Karaktersitik Sosial Petani Padi Sawah di Kecamatan Sawang

\begin{tabular}{|c|c|c|c|c|c|}
\hline & Nama & $\begin{array}{c}\text { Umur } \\
\text { (Tahun) }\end{array}$ & $\begin{array}{c}\text { Pendidikan } \\
\text { (Tahun) }\end{array}$ & Tunglah & $\begin{array}{l}\text { Pengalaman } \\
\text { (Tahun) }\end{array}$ \\
\hline 1 & Idawati & 32 & 9 & 2 & 5 \\
\hline 2 & Rosmani & 50 & 6 & 5 & 40 \\
\hline 3 & Aminah & 53 & 6 & 7 & 40 \\
\hline 4 & Khatijah & 55 & 6 & 2 & 40 \\
\hline 5 & Umar & 60 & 6 & 9 & 40 \\
\hline 6 & Marliah & 31 & 6 & 4 & 10 \\
\hline 7 & Asma & 40 & 9 & 4 & 20 \\
\hline 8 & Usman & 50 & 6 & 3 & 20 \\
\hline 9 & Lida wati & 25 & 6 & 1 & 7 \\
\hline 10 & Fakriah & 40 & 9 & 6 & 30 \\
\hline 11 & Abdurrahman & 45 & 12 & 5 & 10 \\
\hline 12 & Raimah & 53 & 6 & 5 & 30 \\
\hline 13 & Sapiah & 70 & 6 & 12 & 50 \\
\hline 14 & Romida & 47 & 12 & 3 & 20 \\
\hline 15 & Zamidah & 65 & 6 & 4 & 30 \\
\hline 16 & M.taib & 48 & 12 & 3 & 20 \\
\hline 17 & Rohana & 43 & 9 & 3 & 30 \\
\hline 18 & Mahdi & 52 & 12 & 3 & 10 \\
\hline 19 & Zainal Abidin & 71 & 6 & 7 & 40 \\
\hline 20 & M.Nur & 33 & 12 & 2 & 10 \\
\hline 21 & Rajali & 55 & 12 & 4 & 40 \\
\hline 22 & Ruhadayati & 45 & 9 & 4 & 15 \\
\hline 23 & Asiyah & 70 & 6 & 3 & 45 \\
\hline 24 & Jafaruddin & 44 & 12 & 2 & 30 \\
\hline 25 & Nurdin & 45 & 6 & 6 & 30 \\
\hline 26 & Jafar & 50 & 9 & 5 & 35 \\
\hline 27 & Hasanuddin & 30 & 12 & 3 & 30 \\
\hline 28 & Hasanah & 60 & 6 & 5 & 40 \\
\hline 29 & Nurhayati & 50 & 9 & 4 & 30 \\
\hline 30 & Nabsiah & 45 & 6 & 3 & 30 \\
\hline & Rata-rata & 48,56666667 & 8,3 & 4,3 & 27,56666667 \\
\hline & Terendah & 25 & 6 & 1 & 5 \\
\hline & Tertinggi & 71 & 12 & 12 & 50 \\
\hline
\end{tabular}


Lampiran 4. Data Produksi Padi Sawah Petani Sampel di Kecamatan Sawang

\begin{tabular}{|c|c|c|c|}
\hline No & Nama & Luas (Ha) & Produksi (Kg) \\
\hline 1 & Idawati & 0.12 & 1530 \\
\hline 2 & Rosmani & 0.2 & 2210 \\
\hline 3 & Aminah & 0.06 & 340 \\
\hline 4 & Khatijah & 0.24 & 1190 \\
\hline 5 & Umar & 0.2 & 1700 \\
\hline 6 & Marliah & 0.08 & 680 \\
\hline 7 & Asma & 0.16 & 1530 \\
\hline 8 & Usman & 0.12 & 1700 \\
\hline 9 & Lida wati & 0.12 & 255 \\
\hline 10 & Fakriah & 0.328 & 4080 \\
\hline 11 & Abdurrahman & 0.08 & 510 \\
\hline 12 & Raimah & 0.12 & 680 \\
\hline 13 & Sapiah & 0.2 & 850 \\
\hline 14 & Romida & 0.08 & 510 \\
\hline 15 & Zamidah & 0.4 & 2550 \\
\hline 16 & M.taib & 0.08 & 510 \\
\hline 17 & Rohana & 0.12 & 680 \\
\hline 18 & Mahdi & 0.06 & 340 \\
\hline 19 & Zainal Abidin & 0.32 & 2040 \\
\hline 20 & M.Nur & 0.08 & 510 \\
\hline 21 & Rajali & 0.24 & 2550 \\
\hline 22 & Ruhadayati & 0.24 & 2550 \\
\hline 23 & Asiyah & 0.08 & 510 \\
\hline 24 & Jafaruddin & 0.12 & 850 \\
\hline 25 & Nurdin & 0.36 & 4420 \\
\hline 26 & Jafar & 0.2 & 2210 \\
\hline 27 & Hasanuddin & 0.28 & 3230 \\
\hline 28 & Hasanah & 0.24 & 2550 \\
\hline 29 & Nurhayati & 0.24 & 1020 \\
\hline 30 & Nabsiah & 0.28 & 3060 \\
\hline
\end{tabular}


Lampiran 5. Hasil Analisis Regresi pada Usahatani Padi di Kecamatan Sawang Descriptive Statistics

\begin{tabular}{lrrr}
\hline & \multicolumn{1}{c}{ Mean } & Std. Deviation & $\mathrm{N}$ \\
\hline produksi padi & $1.5782 \mathrm{E} 3$ & 1152.92767 & 30 \\
umur & 48.5667 & 11.85162 & 30 \\
pendidikan & 8.3000 & 2.57508 & 30 \\
jumlah tanggungan & 4.3000 & 2.27657 & 30 \\
pengalaman & 27.5667 & 12.52772 & 30 \\
\hline
\end{tabular}

Tabel di atas menunjukkan rata-rata karakteristik sosial petani sampel di Kecamatan Sawang dengan jumlah responden sebanyak 30 orang petani

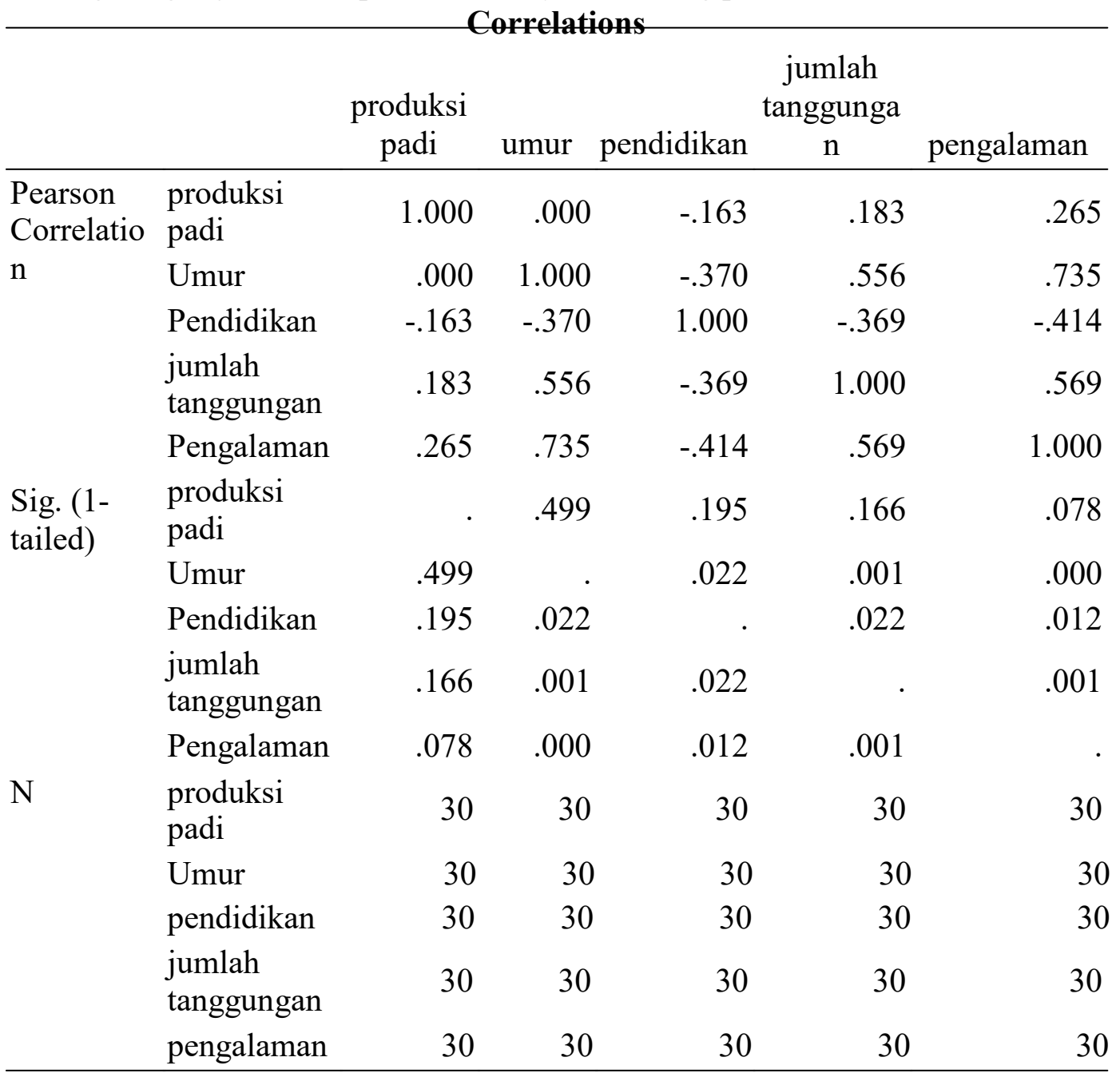




\section{Change Statistics}

R Adjusted Std. Error of R Square F Sig. F DurbinModel $\mathrm{R}$ Square R Square the Estimate Change Change df1 df2 Change Watson

\begin{tabular}{lllllllllll}
\hline 1 & $.414^{\mathrm{a}}$ & .172 & .039 & 1130.20625 & .172 & 1.294 & 4 & 25 & .299 & 2.103 \\
\hline
\end{tabular}

a. Predictors: (Constant), pengalaman, pendidikan, jumlah tanggungan, umur

b. Dependent Variable: produksi padi

\begin{tabular}{|c|c|c|c|c|c|c|c|c|c|}
\hline \multirow{2}{*}{\multicolumn{2}{|c|}{ Model }} & \multicolumn{2}{|c|}{$\begin{array}{l}\text { Unstandardized } \\
\text { Coefficients }\end{array}$} & Coefficients & \multirow{2}{*}{$\mathrm{t}$} & \multirow{2}{*}{ Sig. } & \multicolumn{3}{|c|}{ Correlations } \\
\hline & & B & $\begin{array}{l}\text { Std. } \\
\text { Error }\end{array}$ & Beta & & & $\begin{array}{l}\text { Zero- } \\
\text { order }\end{array}$ & Partial & Part \\
\hline \multirow[t]{5}{*}{1} & (Constant) & 2557.480 & 1395.175 & & 1.833 & .079 & & & \\
\hline & Umur & -46.217 & 27.010 & -.475 & -1.711 & .099 & .000 & -.324 & -.311 \\
\hline & Pendidikan & -36.371 & 91.172 & -.081 & -.399 & .693 & -.163 & -.080 & -.073 \\
\hline & $\begin{array}{l}\text { jumlah } \\
\text { tanggungan }\end{array}$ & 64.804 & 117.168 & .128 & .553 & .585 & .183 & .110 & .101 \\
\hline & Pengalaman & 46.742 & 26.194 & .508 & 1.784 & .086 & .265 & .336 & .325 \\
\hline
\end{tabular}

